\title{
Comparative study of genetic variation and differentiation of two pedunculate oak (Quercus robur) stands using microsatellite and allozyme loci
}

\author{
BERND DEGEN*†, REJANE STREIFF† \& BIRGIT ZIEGENHAGEN§ \\ $\dagger$ INRA Station de Recherches Forestières, Campus agronomique, BP 709, 97387 Kourou cedex, French Guiana, \\ ¥INRA, Station de Recherches Forestières, Laboratoire de Génétique et Amélioration des Arbres Forestiers, BP 45, \\ F-33611 Gazinet cedex, France and §Institut für Forstgenetik und Forstpflanzenzüchtung, Sieker Landstrasse 2, \\ D-22927 Grosshansdorf, Germany
}

\begin{abstract}
In a comparative study four codominant microsatellite loci and seven allozyme gene loci have been used to investigate the genetic variation and differentiation of two pedunculate oak stands in North Germany. Both number and effective number of alleles were five to six times higher and the observed heterozygosity was three times higher for the microsatellite than for the allozyme loci. One stand showed an overall excess of homozygotes. In general the microsatellites were closer to HardyWeinberg expectation. The genetic distances between the two stands were distinctly higher for microsatellites. For most parameters microsatellites exhibited smaller interlocus variation than the allozymes. The different impact of population genetic processes on the genetic structure as assessed by microsatellites or allozymes is discussed.
\end{abstract}

Keywords: allozymes, forest trees, genetic distance, heterozygosity, permutation test, simple sequence repeats.

\section{Introduction}

Genetic variation and differentiation of the pedunculate oak (Quercus robur L.) have been analysed using different gene markers. In many cases allozymes have been applied (Müller-Starck et al., 1993; Bacilieri et al., 1994; Zanetto et al., 1994; Herzog, 1996). As is the case for many other tree species, allozyme studies reveal a low level of genetic differentiation between populations (Müller-Starck \& Ziehe, 1991). In contrast, genetic inventories using maternally inherited chloroplast DNA markers have shown distinct genetic differentiation and an obvious spatial genetic pattern throughout European white oaks (Dumolin-Lapègue et al., 1997; Johnk \& Siegismund, 1997; Ferris et al., 1998). Recently, codominant nuclear microsatellites have been developed and characterized in the genus Quercus (Isagi \& Suhandono, 1997; Steinkellner et al., 1997; Kampfer et al., 1998). These markers have been used to analyse spatial genetic patterns within populations, to perform parentage

\footnotetext{
*Correspondence. E-mail: degen.b@kourou.cirad.fr

-Present address: Laboratorio de biologia molecular, UCTRA,

Universidade do Algarve, 8000 Faro, Portugal.
}

analysis and to reconstruct maternal relatedness within small seedlot samples (Dow \& Ashley, 1996; Streiff et al., 1998; Lexer et al., in press). It has been commonly observed in broad-leaved as well as in coniferous tree species that microsatellites are highly polymorphic markers, thus exhibiting a higher level of genetic variation compared to allozymes (e.g. in oaks: Dow \& Ashley, 1996; Streiff et al., 1998; in pine and Norway spruce: Echt et al., 1996; Pfeiffer et al., 1997). A comparative genetic analysis was conducted for microsatellite and allozyme loci within a mixed stand of Quercus robur and Q. petraea (Streiff et al., 1998), revealing a high potential for spatial genetic differentiation at this scale. However, to our knowledge, nothing is known about the genetic differentiation among oak populations using microsatellite and other markers simultaneously.

In this paper we report on the combined application of allozymes and microsatellites in two different populations of pedunculate oak. The aim was to estimate genetic variation and differentiation and to compare the results obtained using these two different types of gene markers. Both markers are codominant and biparentally inherited (Zanetto et al., 1996; Steinkellner et al., 1997). However, as opposed to allozyme markers, microsatellite 
variation originates from variable numbers of noncoding simple sequence repeat units (Tautz, 1989). Population genetic processes governed by mating system, genetic drift and gene flow are expected to affect both types of markers in the same way leading to similar genetic structures. However, the impact of selection may be different. Hence a comparative analysis may allow different population genetic processes to be distinguished. As an illustration, random mating and absence of genetic drift will lead to Hardy-Weinberg equilibrium for neutral markers whereas selective markers may deviate from Hardy-Weinberg expectations.

\section{Materials and methods}

\section{Study stands}

The two stands are located in North Germany $\approx 40 \mathrm{~km}$ south-west of Lübeck. According to the names of the nearby villages they are called 'Behlendorf' and 'Steinhorst', respectively. The distance between the stands is about $15 \mathrm{~km}$. Both sites represent mixed stands of Fagus sylvatica, Quercus robur and Carpinus betulus. The oaks were artificially regenerated using seeds and saplings of local origin. All adult oaks in both stands ('Behlendorf': $N=228$, 'Steinhorst': $N=85$ ) were sampled. According to the recorded history, the sampled trees in 'Behlendorf' are between 180 and 210 years old and the trees in 'Steinhorst' between 150 and 259 years old. For both microsatellite and allozyme analysis, winter buds were collected.

\section{Microsatellites}

DNA extraction Total DNA was isolated from the buds after removing the scales. Five to six buds were prefrozen in liquid nitrogen and the DNA extracted according to the minipreparation of Dumolin et al. (1995) with slight modifications, including a final treatment with $0.5 \mu \mathrm{g}$ RNaseA (Boehringer Mannheim, Germany) at $37^{\circ} \mathrm{C}$ for $30 \mathrm{~min}$.

Microsatellite analysis Four microsatellite loci were analysed and the sequence information of the relevant primer pairs was taken from Steinkellner et al. (1997). According to Steinkellner et al. (1997) the loci are coded ssrQpZAG36, ssrQpZAG1/5, ssrQpZAG9 and ssrQpZAG104. All four are characterized by variable numbers of (AG)-repeats. Furthermore they follow simple codominant Mendelian inheritance (Steinkellner et al., 1997).

PCR amplification PCR amplification was carried out in a total volume of $25 \mu \mathrm{L}$ containing about $20 \mathrm{ng}$ of template DNA, $2.5 \mathrm{~mm} \mathrm{MgCl} 2,100 \mu \mathrm{M}$ of each dNTP,
$0.2 \mu \mathrm{M}$ of each primer and $0.25 \mathrm{U}$ of Taq polymerase with the respective $1 \times$ PCR buffer (Taq polymerase and $10 \times$ PCR buffer were purchased from Eurogentec, Ougree, Belgium), following the cycle profile described by Streiff et al. (1998). PCR was run in the Touch-Down ${ }^{\mathrm{TM}}$ Thermal System (Hybaid Limited, Teddington, UK).

Separation and staining of PCR products The PCR products were pretreated according to Streiff et al. (1998) and run in a 6\% denaturing polyacrylamide gel (Rotiphor 40, 38:2 acrylamide:bisacrylamide, Pharmacia, Freiburg, Germany), using sequencing gel apparatus (S2 Gibco BRL, Life Technologies, Eggenstein, Germany). The gels were run in $1 \times$ TBE buffer adjusted to $\mathrm{pH} 8.3$ at $2000 \mathrm{~V}$ for $2.5-3 \mathrm{~h}$. Silver staining of the gels was performed according to Streiff et al. (1998). A standard was constructed using the DNA of probes with different alleles. This standard was run every 5 or 10 lanes on each gel. The allelic variation of each sample was assessed by comparison to this standard.

\section{Allozymes}

For allozyme analysis, crude proteins were extracted from winter buds. Extraction procedures and the composition of the electrode and gel buffers followed those of Hertel \& Zaspel (1996). Stains were adapted from Yeh \& O'Malley (1980), Vallejos (1983) and Cheliak \& Pitel (1984).

From the enzyme systems studied seven polymorphic loci that showed simple Mendelian inheritance in controlled crosses (Zanetto et al., 1996) were used: $A a p-b$ (alanine aminopeptidase), Pgi- $b$ (phosphoglucoisomerase), $\mathrm{Mnr}$ (menadione reductase), $6 p g d h-b$ (6-phosphogluconate dehydrogenase), Idh- $b$ (isocitrate dehydrogenase), Pgm (phosphoglucomutase) and Acp-c (acid phosphatase). Aap-b, Acp-c and Pgm were monomeric, 6pgdh-b, Idh-b and Pgi-b were dimeric and Mnr was tetrameric.

\section{Data analysis}

For each locus, allele frequencies $\left(p_{i j}\right)$, the number of different alleles $(A)$, observed heterozygosity $\left(H_{\mathrm{o}}\right)$, expected heterozygosity $\left(H_{\mathrm{e}}\right)$, the effective number of alleles $\left(A_{\mathrm{e}}=1 /\left(1-H_{\mathrm{e}}\right)\right)$, and the fixation index $\left(F=1-\left(H_{\mathrm{o}} /\right.\right.$ $\left.\left.H_{\mathrm{e}}\right)\right)$ were calculated as described by Weir (1990).

Two different genetic distances were applied to quantify genetic differentiation: $D_{\mathrm{G}}$ (Gregorius, 1978) and $D_{\mathrm{N}}(\mathrm{Nei}, 1972)$ :

$$
D_{\mathrm{G}}(i, j)=\frac{1}{2} \cdot \sum_{k=1}^{n}\left|p_{i k} \quad p_{j k}\right| \quad \text { and }
$$

(c) The Genetical Society of Great Britain, Heredity, 83, 597-603. 
$D_{\mathrm{N}}(i, j)=\ln \left(\frac{\sum_{k=1}^{n}\left(p_{i k} \cdot p_{j k}\right)}{\sqrt{\sum_{k=1}^{n} p_{i k}^{2} \cdot \sum_{k=1}^{n} p_{j k}^{2}}}\right)$,

where $i$ and $j$ represent two populations, $n$ is the number of alleles and $p_{i k}$ is the relative frequency of the $k$ th allele in the $i$ th population. Additional information is obtained by the measure $D_{\mathrm{G}}$, as it may be used to compute the genetic distance between the genotype frequencies of two populations.

To estimate the significance of $F, A_{\mathrm{e}}, D_{\mathrm{G}}$ and $D_{\mathrm{N}}$, numerical tests were performed on the basis of Monte Carlo methods (Manly, 1991). To test the significance of the $F$-values for each population and each locus, 1000 permutations of the genotypes were run. Each permutation leads to a new random association of the alleles of the respective population (resampling without replacement). After each permutation the $F$-values were recalculated and compared to the observed values. The relative frequency of those cases leading to less extreme $F$-values than the observed values were used to estimate the probability of significant deviation from the HardyWeinberg expectation.

One-thousand permutations, with random resampling of single-locus genotypes from both populations, were carried out to test for significant differences of $A_{\mathrm{e}}$ between the two populations. After permutation the genotypic structure of each population represents a random mixture of genotypes from both original populations. The $A_{\mathrm{e}}$ values were calculated for both resampled populations ( $i$ and $j$ ). Within each permutation the mathematical difference (Dif) between the $A_{\mathrm{e}}$ values from the two resampled populations was computed $\left(D i f_{i j}=A_{\mathrm{e}}(i)-A_{\mathrm{e}}(j)\right)$. The permutations led to a certain distribution of the pairwise differences (Dif). The relative frequency of those cases with a less extreme difference (Dif) than that observed was used to estimate the probability of a significant difference of the $A_{\mathrm{e}}$ values between the two stands. In the same way the significance of the genetic distances, $D_{\mathrm{G}}$ and $D_{\mathrm{N}}$, was tested. After each permutation $D_{\mathrm{G}}$ and $D_{\mathrm{N}}$ were recalculated and compared to the original values. The relative frequency of those cases with distances smaller than the observed was used to estimate the probability of significance.

The significance of mean parameters (difference $A_{\mathrm{e}}, F$, $D_{\mathrm{G}}$ and $D_{\mathrm{N}}$ ) was determined according to the testing procedure for the single loci. For each permutation the means were recalculated and compared to the mean of the original data. The relative frequency of those cases with means smaller than the observed was used to estimate the probability of significance.
The coefficient of variation $(\mathrm{CV}=$ standard deviation/arithmetic mean) was calculated to quantify the interlocus variation of the parameters.

\section{Results}

Genetic variation and differentiation results are summarized in Tables 1 and 2. As shown by the sample sizes in Table 1, not all of the sampled individuals provided microsatellite or allozyme data.

\section{Genetic variation}

On average the microsatellite loci had five to six times more alleles $(A)$, as well as effective number of alleles $\left(A_{\mathrm{e}}\right)$, than the allozyme loci (Table 1). The observed heterozygosity $\left(H_{\mathrm{o}}\right)$ was three times greater for microsatellites than for allozymes. For both categories of markers, the 'Behlendorf' stand was characterized by higher values of genetic variation ( $A$ and $A_{\mathrm{e}}$ ). At locus $P g i-b$ the difference in the effective number of alleles $\left(A_{\mathrm{e}}\right)$ between the two stands was significant. In general the observed heterozygosity $\left(H_{\mathrm{o}}\right)$ was similar between the two populations for both categories of markers. The mean observed heterozygosity $\left(H_{\mathrm{o}}\right)$ for the allozymes was slightly greater in the 'Steinhorst' stand than in the 'Behlendorf' stand. In 'Behlendorf' the mean fixation index $(F)$ was significantly positive for the allozymes and significantly negative for the microsatellites. In 'Steinhorst' the mean fixation indices $(F)$ for allozymes and microsatellites were not significantly different from Hardy-Weinberg expectation. However, two single-locus $F$-values showed deviations from Hardy-Weinberg expectation: the fixation index for the locus ssrQpZAG1/5 was highly significantly negative, whereas it was significantly positive for the locus Aap- $b$. The overall means including both categories of markers revealed a significant positive deviation from Hardy-Weinberg expectation for 'Behlendorf', whereas 'Steinhorst' was in equilibrium. As revealed by the mean fixation index $(F)$, the microsatellites were closer to Hardy-Weinberg expectation than the allozymes. The coefficients of variation (CV) showed smaller interlocus variation of $A_{\mathrm{e}}, H_{\mathrm{o}}$ and $F$ for the microsatellites than for the allozymes.

\section{Genetic differentiation}

At allozyme locus Pgm and at the microsatellite locus ssrQpZAG9 the genetic distance $D_{\mathrm{G}}$, based on the genotype distribution between 'Behlendorf' and 'Steinhorst', was statistically significant (Table 2). There were no significant genetic distances between the allelic distributions. The gene pool distance $D_{\mathrm{G}}$ was 4.4 and 
Table 1 Sample size $(N)$, number of alleles $(A)$, effective number of alleles $\left(A_{\mathrm{e}}\right)$, observed heterozygosity $\left(H_{\mathrm{o}}\right)$ and fixation index $(F)$ for the oak stands 'Behlendorf' (Behl.) and 'Steinhorst' (Stein.) at 11 allozyme (italic) and microsatellite loci; probability of significant difference in $A_{\mathrm{e}}($ Prob. Dif) between the two stands; probability for test of significance for deviation from Hardy-Weinberg expectation (Prob. F); coefficient of variation $(\mathrm{CV}=$ standard deviation/ arithmetic mean)

\begin{tabular}{|c|c|c|c|c|c|c|c|c|c|c|c|c|c|}
\hline \multirow[b]{2}{*}{ Locus } & \multicolumn{2}{|c|}{$N$} & \multicolumn{2}{|c|}{$A$} & \multicolumn{3}{|c|}{$A_{\mathrm{e}}$} & \multicolumn{2}{|c|}{$H_{\mathrm{o}}$} & \multicolumn{4}{|c|}{$F$} \\
\hline & Behl. & Stein. & Behl. & Stein. & Behl. & Stein. & Prob. Dif & Behl. & Stein. & Behl. & Prob. $F$ & Stein. & Prob. $F$ \\
\hline$A a p-b$ & 223 & 83 & 4 & 4 & 2.85 & 2.98 & 0.876 & 0.574 & 0.566 & +0.117 & 0.987 & +0.149 & 0.966 \\
\hline$P g i-b$ & 228 & 84 & 4 & 2 & 1.28 & 1.15 & 0.971 & 0.206 & 0.119 & +0.081 & 0.899 & +0.098 & 0.790 \\
\hline$M n r$ & 228 & 85 & 4 & 4 & 1.21 & 1.18 & 0.650 & 0.180 & 0.165 & -0.049 & 0.851 & -0.061 & 0.825 \\
\hline $6 p g d h-b$ & 224 & 85 & 3 & 2 & 1.07 & 1.07 & 0.448 & 0.063 & 0.071 & +0.095 & 0.870 & -0.037 & 0.738 \\
\hline$I d h-b$ & 222 & 85 & 2 & 2 & 1.64 & 1.63 & 0.530 & 0.338 & 0.412 & +0.139 & 0.967 & -0.058 & 0.704 \\
\hline$P g m$ & 207 & 83 & 3 & 4 & 2.08 & 2.03 & 0.673 & 0.319 & 0.506 & +0.387 & 1.000 & +0.004 & 0.515 \\
\hline$A c p-c$ & 201 & 85 & 3 & 2 & 1.54 & 1.54 & 0.528 & 0.313 & 0.341 & +0.108 & 0.893 & +0.035 & 0.655 \\
\hline ssrQpZAG36 & 213 & 85 & 17 & 13 & 7.90 & 7.85 & 0.313 & 0.878 & 0.882 & -0.005 & 0.634 & -0.011 & 0.664 \\
\hline ssrQpZAG1/5 & 219 & 80 & 15 & 12 & 7.25 & 6.57 & 0.675 & 0.895 & 0.938 & -0.038 & 0.948 & -0.106 & 0.995 \\
\hline ssrQpZAG9 & 210 & 83 & 14 & 11 & 7.62 & 6.65 & 0.797 & 0.876 & 0.843 & -0.009 & 0.681 & +0.007 & 0.507 \\
\hline ssrQpZAG104 & 214 & 81 & 33 & 28 & 13.40 & 12.64 & 0.394 & 0.944 & 0.921 & -0.020 & 0.906 & +0.008 & 0.523 \\
\hline Mean (allozymes) & & & 3.28 & 2.85 & 1.66 & 1.65 & 0.880 & 0.285 & 0.311 & +0.125 & 1.000 & +0.019 & 0.677 \\
\hline Mean (microsatellites) & & & 19.75 & 16 & 9.04 & 8.42 & 0.836 & 0.898 & 0.894 & -0.018 & 0.960 & -0.025 & 0.941 \\
\hline Mean (total) & & & 9.25 & 7.63 & 2.16 & 2.10 & 0.814 & 0.509 & 0.523 & +0.073 & 1.000 & +0.003 & 0.483 \\
\hline CV (allozymes) & & & 0.21 & 0.34 & 0.34 & 0.37 & & 0.52 & 0.58 & 0.96 & & 4.02 & \\
\hline CV (microsatellites) & & & 0.39 & 0.43 & 0.27 & 0.29 & & 0.03 & 0.04 & 0.71 & & 1.84 & \\
\hline
\end{tabular}


Table 2 Genetic distance $D_{\mathrm{G}}$ (Gregorius, 1978) and genetic distance $D_{\mathrm{N}}$ (Nei, 1972) between the distributions of genotypes and allele frequencies of the oak stands 'Steinhorst' and 'Behlendorf' for 11 allozyme (italic) and microsatellite loci; CV, coefficient of variation $(\mathrm{CV}=$ standard deviation/arithmetic mean)

\begin{tabular}{|c|c|c|c|c|c|c|}
\hline \multirow[b]{2}{*}{ Locus } & \multicolumn{2}{|c|}{ Distribution of genotypes } & \multicolumn{4}{|c|}{ Distribution of alleles } \\
\hline & $D_{\mathrm{G}}$ & Probability & $D_{\mathrm{G}}$ & Probability & $D_{\mathrm{N}}$ & Probability \\
\hline$A a p-b$ & 0.093 & 0.187 & 0.055 & 0.489 & 0.006171 & 0.505 \\
\hline$P g i-b$ & 0.097 & 0.899 & 0.054 & 0.915 & 0.000897 & 0.753 \\
\hline$M n r$ & 0.030 & 0.122 & 0.015 & 0.174 & 0.000086 & 0.113 \\
\hline 6pgdh-b & 0.013 & 0.203 & 0.002 & 0.040 & 0.000004 & 0.040 \\
\hline$I d h-b$ & 0.074 & 0.653 & 0.003 & 0.083 & 0.000015 & 0.083 \\
\hline$P g m$ & 0.232 & 0.998 & 0.105 & 0.933 & 0.018098 & 0.915 \\
\hline Acp-c & 0.033 & 0.178 & 0.006 & 0.053 & 0.000034 & 0.065 \\
\hline ssrQpZAG36 & 0.366 & 0.277 & 0.150 & 0.842 & 0.035364 & 0.746 \\
\hline ssrQpZAG1/5 & 0.410 & 0.774 & 0.141 & 0.847 & 0.031069 & 0.779 \\
\hline ssrQpZAG9 & 0.433 & 0.961 & 0.150 & 0.895 & 0.053617 & 0.944 \\
\hline ssrQpZAG104 & 0.616 & 0.203 & 0.166 & 0.304 & 0.034050 & 0.202 \\
\hline Gene pool (allozymes) & - & - & 0.034 & 0.493 & 0.002748 & 0.700 \\
\hline Gene pool (microsatellites) & - & - & 0.151 & 0.906 & 0.039396 & 0.880 \\
\hline Gene pool (total) & - & - & 0.077 & 0.793 & 0.006197 & 0.808 \\
\hline CV (allozymes) & 0.83 & & 1.04 & & 1.73 & \\
\hline CV (microsatellites) & 0.20 & & 0.05 & & 0.22 & \\
\hline
\end{tabular}

the gene pool distance $D_{\mathrm{N}}$ was 14.3 times greater for microsatellites than for allozymes. As indicated by the coefficients of variation $(\mathrm{CV})$, the interlocus variation of the genetic distances was clearly higher for the allozymes than for the microsatellites. For the loci Pgi-b and ssrQpZAG104, and for the gene pool of allozymes, the calculated probabilities of the two distance measures $\left(D_{\mathrm{G}}\right.$ and $\left.D_{\mathrm{N}}\right)$ differed by more than $10 \%$. In all other cases the differences of the probabilities were less than $10 \%$. Both distance measures seem to be equally sensitive for detecting genetic differences.

\section{Discussion}

DNA polymorphisms have increasingly become validated as markers in the population genetics of forest trees, and thus comparative analyses allow the application of different categories of markers to the same populations. To evaluate different population genetic processes, different genetic markers may be useful, depending on their origin in coding or noncoding DNA regions, on differences in the mutation rates and processes, on their mode of transmission, and on the degree of resolution of the detection technique. In our study, we simultaneously applied two different categories of biparentally inherited codominant genetic markers, one originating from coding sequences (allozymes) and the other from sequences of the nuclear genome that, as is common for microsatellites, are of a noncoding nature (Tautz, 1989). In this study, as well as in previous studies, null alleles have so far not been observed at any of the four microsatellite loci here analysed (H. Steinkellner, pers. comm.).

In accordance with a previous study (Streiff et al., 1998) we found a higher level of variation for microsatellite than for allozyme gene loci. For a stand of Quercus robur in north-western France, Streiff et al. (1998) found a mean number of alleles $A=19.75$ and a mean effective number of alleles $A_{\mathrm{e}}=9.95$, analysing the same microsatellite loci as in the present study. The values assessed in the French stand were four to six times higher for the microsatellite loci than for the allozyme loci. The genetic variation of the French stand, based on microsatellite loci, is very similar to that for the 'Behlendorf' stand.

The ranking of genetic variation $\left(A\right.$ and $\left.A_{\mathrm{e}}\right)$ between the two stands, 'Behlendorf' and 'Steinhorst', is the same for both categories of gene markers; the differences were greater for microsatellites. Only for one allozyme locus was the difference of $A_{\mathrm{e}}$ between the stands statistically significant. The lower sample size in the 'Steinhorst' stand may be a simple explanation for the lower values of genetic variation compared to 'Behlendorf'. Because of the greater number of low frequency alleles, microsatellites are expected to be more sensitive to differences in sample size; sampling error is assumed to be higher (Gregorius, 1980; Krusche \& Geburek, 1991). Hence genetic variation differences between populations based on microsatellites may fail to be statistically significant. However, bottleneck effects in population history may be easier to detect for highly variable loci (Aldrich et al., 1998). 
The mean fixation index $(F)$ for all 11 loci was significantly positive in the 'Behlendorf' stand. In contrast, the mean value of 'Steinhorst' did not show significant deviation from Hardy-Weinberg expectation. Inbreeding and the Wahlund effect could have caused the significant excess of homozygotes in 'Steinhorst'. In both stands the mean $F$-values of the allozymes were positive (excess of homozygotes) and the values for the microsatellites were slightly negative (excess of heterozygotes). If the mating system were the only process responsible for deviation from Hardy-Weinberg equilibrium, we would expect $F$-values for all biparentally inherited codominant genetic markers to show the same trends (Wright, 1965). In some cases heterozygosity may be slightly overestimated for microsatellites, because of uncertainties in assigning the status of homozygotes when slippage bands interfere with the main 'allelic' bands. Problems arising from misinterpretation of slippage bands have been reported in the literature several times (e.g. Perlin et al., 1995). This misinterpretation could explain the negative $F$-values of microsatellites. Streiff et al. (1998) also report higher $F$-values for allozymes than for microsatellites in an oak population.

The genetic distances, $D_{\mathrm{G}}$ and $D_{\mathrm{N}}$, between both populations are clearly higher for microsatellites than for allozymes, but the higher distances did not include more significant differences. As for most of the other parameters (see $A_{\mathrm{e}}, H_{\mathrm{o}}$ ) the interlocus variation of the distances $D_{\mathrm{G}}$ and $D_{\mathrm{N}}$ is smaller for the microsatellites than for allozymes. Therefore, allozymes are more likely to reveal the impact of different and contrasting population genetic processes, whereas microsatellite variation reflects less interaction of population processes. The main difference may be the impact of selection, which could be stronger for allozymes. For tree populations, many studies have described the effect of selection on allozymes (e.g. Kim, 1985; Müller-Starck, 1985; for review see also Mitton, 1995). In contrast, microsatellites are supposed to be unaffected by selection, as long as they are not 'hitchhiking' with, or in sequences that are subjected to selection (e.g. Jarne \& Lagoda, 1996).

The combined application of different gene markers, such as allozymes and microsatellites, is helpful to distinguish the impact of the various population genetic processes. In particular, a combination of 'neutral' and 'selective' markers helps to understand better the role of the mating system, selection and bottleneck effects in determining genetic structure. As demonstrated by our study, numerical tests using Monte Carlo methods provide powerful statistical tests for highly variable markers. In contrast to other statistics like the $G$-test or $\chi^{2}$-test, no distributional assumptions are required for these numerical tests.

\section{Acknowledgements}

The work was financially supported by the EU (Programme Biotechnology, BIO4-CT96-0706) and by a grant from the German Ministry of Food, Agriculture and Forestry. We thank Alexandra Tusch and Vivian Kuhlenkamp for their excellent work in the lab. Many thanks are given to the students Ole Ziemer and Katrin Schwarz for assisting in the field work: measuring the locations of the trees and collecting the buds. We are grateful to Florian Scholz for his support and wish to thank two anonymous reviewers for helpful commentary.

\section{References}

ALDRICH, P. R., HAMRICK, J. L., CHAVARRIAGA, P. AND KOCHERT, G. 1998. Microsatellite analysis of demographic genetic structure in fragmented populations of the tropical tree Symphonia globulifera. Mol. Ecol., 7, 933-944.

BACILIERI, R., LABBE, T. AND KREMER, A. 1994. Intraspecific genetic structure in a mixed population of Quercus petraea (Matt.) Liebl. and Q. robur L. Heredity, 73, 130-141.

CHELIAK, w. M. AND PITEL, J. A. 1984. Techniques for Starch Gel Electrophoresis of Enzymes from Forest Tree Species. Information Report PI-X-42, Petawawa National Forestry Institute.

DOW, B. D. AND ASHLEY, M. V. 1996. Microsatellite analysis of seed dispersal and parentage of saplings in bur oak, Quercus macrocarpa. Mol. Ecol., 5, 615-627.

DUMOLIN, S., DEMESURE, B. AND PETIT, R. J. 1995. Inheritance of chloroplast and mitochondrial genomes in pedunculate oak investigated with an efficient PCR method. Theor. Appl. Genet., 91, 1253-1256.

DUMOLIN-LAPĖGUE, S., DEMESURE, B., FINESCHI, S., LE CORRE, V. AND PETIT, R. J. 1997. Phylogeographic structure of white oaks throughout the European Continent. Genetics, 146, 1475-1487.

ECHT, C. S., MAY-MARQUARDT, P., HSEIH, M. AND ZAHORCHAK, R. 1996. Characterization of microsatellite markers in eastern white pine. Genome, 39, 1102-1108.

FERRIS, C., KING, R. A., VAINOLA, R. AND HEWITT, G. M. 1998. Chloroplast DNA recognizes three refugial sources of European oaks and suggests independent eastern and western immigrations to Finland. Heredity, 80, 584-593.

GREGORIUS, H.-R. 1978. The concept of genetic diversity and its formal relationship to heterozygosity and genetic distance. Math. Biosciences, 41, 253-271.

GREGORIUS, H.-R. 1980. The probability of losing an allele when diploid genotypes are sampled. Biometrics, 36, 643-652.

HERTEL, H. AND ZASPEL, I. 1996. Investigations on vitality and genetic structure in oak stands. Ann. Sci. For., 53, 761-773.

HERZOG, s. 1996. Genetic inventory of European oak populations: Consequences for breeding and gene conservation. Ann. Sci. For., 53, 783-793.

ISAGI, Y. AND SUHANDONO, s. 1997. PCR primers amplifying microsatellite loci of Quercus myrsinifolia Blume and their conservation between oak species. Mol. Ecol., 6, 897-899. 
JARNE, P. AND LAGODA, J. L. 1996. Microsatellites, from molecules to populations and back. Trends Ecol. Evol., 11, 424-429.

JOHNK, N. AND SIEGISMUND, H. R. 1997. Population structure and post-glacial migration routes of Quercus robur and Quercus petraea in Denmark, based on chloroplast DNA analysis. Scand. J. For. Res., 12, 130-137.

KAMPFER, S., LEXER, C., GLÖSSL, J. AND STEINKELLNER, H. 1998. Characterization of $(G A) n$ microsatellite loci from Quercus robur. Hereditas, 129, 183-186.

KIM, Z. S. 1985. Viability selection at an allozyme locus during development in European beech (Fagus sylvatica L.). Silvae Genet., 34, 181-186.

KRUSCHE, D. AND GEBUREK, T. 1991. Conservation of forest gene resources as related to sample size. For. Ecol. Management, 40, 145-150.

LEXER, C., HEINZE, B., STEINKELLNER, H., KAMPFER, S., ZIEGENHAGEN, B. AND GLÖSSL, J. Microsatellite analysis of maternal half-sib families of Quercus robur, pedunculate oak: Detection of seed contaminations and inference of the seed parents from the offspring. Theor. Appl. Genet. (in press).

MANLY, B. F. J. 1991. Randomization and Monte Carlo Methods in Biology. Chapman \& Hall, London.

MitTON, J. B. 1995. Genetics and the physiological ecology of conifers. In: Smith, W. K. and Hinckley, T. M. (eds) Ecophysiology of Coniferous Forests, pp. 1-35. Academic Press, New York.

MÜLLER-STARCK, G. 1985. Genetic differences between 'tolerant' and 'sensitive' beeches (Fagus sylvatica L.) in an environmentally stressed adult forest stand. Silvae Genet., 34, 241-247.

MÜLLER-STARCK, G. AND ZIEHE, M. (eds) 1991. Genetic Variation in European Populations of Forest Trees. J. D. Sauerländer's Verlag, Frankfurt.

MÜLLER-STARCK, G., HERZOG, S. AND HATTEMER, H. H. 1993. Intra- and interpopulational genetic variation in juvenile populations of Quercus robur L. and Quercus petraea Liebl. Ann. Sci. For., 50, 233-244.
NEI, M. 1972. Genetic distance between populations. Am. Nat., 106, 283-292.

PERlin, M. W., LANCIA, G. AND NG, S. K. 1995. Toward fully automated genotyping: Genotyping microsatellite markers by deconvolution. Am. J. Hum. Genet., 57, 1199-1210.

PFEIFFER, A., OLIVIERI, A. M. AND MORGANTE, M. 1997. Identification and characterization of microsatellites in Norway spruce (Picea abies K.). Genome, 40, 411-419.

STEINKELlNer, H., FlUCh, S., TURETSCHEK, E., LEXER, C., STREIFF, R., KREMER, A. ET AL. 1997. Identification and characterization of $(\mathrm{GA} / \mathrm{CT})(n)$-microsatellite loci from Quercus petraea. Plant Mol. Biol., 33, 1093-1096.

STREIFF, R., LABBE, T., BACILIERI, R., STEINKELLNER, H., GLÖSSL, J. AND KREMER, A. 1998. Within-population genetic structure in Quercus robur L. and Quercus petraea (Matt.) Liebl. assessed with isozymes and microsatellites. Mol. Ecol., 7, 317-328.

TAUTZ, D. 1989. Hypervariability of simple sequences as a general source for polymorphic DNA markers. Nucl. Acids Res., 17, 6463-6471.

VALLEJOS, C. E. 1983. Enzyme activity staining. In: Tanskley, S. D. and Orton, T. J. (eds) Isozymes in Plant Genetics and Breeding, pp. 469-516. Elsevier, Amsterdam.

WEIR, B. S. 1990. Genetic Data Analysis. Sinauer Associates, Sunderland, MA.

WRIGHT, S. 1965. The interpretation of population structure by $F$-statistics with special regard to systems of mating. Evolution, 19, 395-420.

YEH, F. C. AND O'MALLEY, D. M. 1980. Enzyme variations in natural populations of Douglas-fir, Pseudotsuga menziesii (Mirb.) Franco, from British Columbia. I. Genetic variation patterns in coastal populations. Silvae Genet., 29, 83-92.

ZANETTO, A., ROUSSEL, G. AND KREMER, A. 1994. Geographic variation of interspecific differentiation between Quercus robur L. and Quercus petraea Matt. (Liebl.). For. Genet., 1, 111-123.

ZANETTO, A., KREMER, A., MÜLLER-STARCK, G. AND HATTEMER, H. H. 1996. Inheritance of isozymes in pedunculate oak (Quercus robur L.). J. Hered., 87, 364-370. 